\title{
As bodas de vinho de uma tragédia profética: Anjo negro (1946), de Nelson Rodrigues
}

The marriage of wine of a prophetic tragedy: Anjo negro (1946), by Nelson Rodrigues

Dênis Moura de Quadros ${ }^{1}$ 


\section{Resumo}

A tragédia rodriguiana Anjo negro (1946) foi encenada pela primeira vez em 1948 no teatro fênix, no Rio de Janeiro. Passando pela censura e a interdição racista que não permitiu que Abdias do Nascimento (1914-2011) atuasse no papel do "Grande Negro". Este artigo retoma a textualidade dramática da peça destacando a presença constante da morte e de "estilhaços" das tragédias áticas. A leitura aqui realizada prima pela teoria da gorgonopoética (Quadros, 2018) em que esses escritos da/para morte perpassam a monstruosidade, logo, Gorgó Medusa ao invés da morte heroica de Tânatos.

Palavras-chave: Gorgonopoética; tragédia; dramaturgia brasileira

\section{Abstract}

The tragedy rodriguiana Anjo negro (1946) was staged for the first time in 1948 at the Phoenix Theatre in Rio de Janeiro. Going through censorship and the racist interdiction that did not allow Abdias do Nascimento (1914-2011) to act on the role of the "Great Negro". This article resumes the dramatic textuality of the piece highlighting the constant presence of death and "shrapnel" from the attic tragedies. The reading here carried out by the theory of gorgonopoética (Quadros, 2018) in which these writings from/to death permeate the monstrosity, soon Gorgó Medusa instead of the heroic death of Tantatos.

Keywords: Gorgonopoetic; tragedy; Brazilian dramaturgy

E-ISSN: 2358.6958 
No ano em que Anjo negro (1946) completa 70 anos de encenação, percebemos um insistente silêncio da Academia em que não vemos uma única homenagem ao dramaturgo brasileiro lembrado, quase somente, por Vestido de noiva (1943). Contudo, percebemos que as análises acerca da peça ainda não exauriram e, que a textualidade dramática permite outras leituras além das já feitas ${ }^{2}$. Entendo textualidade dramática como um texto que precisa de um corpo para ser completo, um texto que não é um produto, fechado e acabado, que precisa ser complementado pelo espetáculo. Assim, retomamos a leitura sob a óptica da gorgonopoética: "o estudo de escrituras que, independente de seus gêneros, são 'embriagadas' pela morte. Essas escrituras, em especial as dramáticas, fazem com que alguns sentimentos e experiências anteriores sejam emergidos" (Quadros, 2018, p. 45).

Nelson Rodrigues fazia uma distinção entre as características marcantes de seus personagens apresentando as duas partes que nos compõe: a divina que nos faz diferente de outros animais e a parte animal que nos equipara aos outros animais pela mortalidade. Na tradição órfica essas duas faces desdobram-se no nosso lado titânico e no nosso olímpico pela origem humana das cinzas dos Titãs que ingeriram o Dioniso-Zagreu. Além disso, a morte na Grécia Antiga, também, apresentava duas faces: a face gloriosa de Tânatos e o horror em grau superlativo no grito silencioso de Gorgó. Adriana Facina (2004) reflete em seu estudo antropológico acerca da obra dramática rodriguiana que esses personagens se dividem em dois distintos grupos.

Para Nelson Rodrigues, todos os homens têm em si duas metades, uma "face linda" e outra "face hedionda", centauros parcialmente Deus e parcialmente Satã [...]. Os santos, além de bons e virtuosos, eram caracterizados pela renúncia aos instintos que Nelson considerava desumanizadores e por uma existência pautada em um forte sentido ético-moral. Já os canalhas eram seres amorais por excelência, que não reconheciam limites para a satisfação de seus desejos. (Facina, 2004, p. 15)

As protagonistas das peças míticas não apresentam a renúncia aos instintos, considerados pelo dramaturgo como integrantes da parte maldita, ao contrário, elas estão totalmente entregues e inclinadas aos instintos. Anjo negro (1946) gira em torno da casa em que vive Ismael e Virgínia, ele médico negro que se veste todo de branco e que não mais trabalha, tendo juntado uma pequena fortuna. Ela branca, criada pela tia na mesma casa que agora reside em cárcere privado. Virgínia é uma personagem instável que oscila em dois momentos: Um de repúdio ao esposo e outro de desejo exacerbado.

Anjo a presença constante do racismo é o gatilho para o sacrifício dos meninos e a conivência de Ismael, bem como seus dois crimes: cegar Elias, o irmão de criação branco e Ana Maria, a filha de Elias com Virgínia. Nelson Rodrigues afirma que não há racismo mais cruel no Brasil do que aquele advindo do próprio negro. O protagonista Ismael é um presente do dramaturgo para o ator Abdias do Nascimento (1914-2011), contudo a censura libera a peça, mas não permite que Abdias represente Ismael pela presença de cenas entre o negro e a branca (Magaldi, 2004), quem interpreta Ismael é Orlando Guy através da técnica racista blackface.

2 Este trabalho foi financiado pela Coordenação de Aperfeiçoamento de Pessoal de Nível Superior (CAPES) através de bolsa de fomento. 
A presença da morte é constante em Anjo negro (1946), ela quem abre a peça com a morte do terceiro filho negro do casal, Ismael e Virgínia, e ela quem encerra a peça com a morte de Ana Maria, filha de Virgínia com Elias. Assim como em Álbum de família (1945) peça mítica e desagradável em que a família está ao centro evocando e instaurando mitos e fantasmas, em Anjo ela também executa essa função, contudo há um atenuante nessa relação: o racismo de Ismael contra ele mesmo.

A peça rompe com os conceitos e noções de tempo e espaço, apesar do lapso cronológico entre o segundo e o terceiro ato que irrompe na puberdade de Ana Maria, os dias não avançam na casa do médico Ismael, pois o sol nunca nasce. Na rubrica que abre peça o dramaturgo afirma que o cenário não apresenta: "nenhum caráter realista" (Rodrigues, 1981, p. 125, 1ำ quadro do 1ํato) apresentando um caixão branco, de "anjos" com quatro círios rodeados pelo coro de dez senhoras negras. Além disso, a presença da cama de solteira de Virgínia intocavelmente quebrada. Ainda essa "casa não tem teto para que a noite possa entrar e possuir os moradores" cercados por grandes e altos muros.

Ismael é médico, veste-se de terno branco, chapéu estilo panamá também branco e sapatos de verniz. Sua imagem lembra o arquétipo do malandro que é baseado na figura mítico-religiosa de Zé Pelintra, cultuado nas mesas de Jurema, Catimbó, Umbanda e Quimbanda. Contudo, Ismael não é o desdobramento dessa figura, o branco de sua roupa busca esconder o negrume de sua pele. Desde pequeno ele nega ser negro e, mais do que isso, tem ódio de ser negro. Com o tempo seu ódio fora sendo alimentado pela negação das crenças e atos que, segundo Ismael, caracterizam os negros como, por exemplo, beber cachaça ou rezar para São Jorge considerado "santo de preto". Sua fixação por ser branco é levada ao extremo ao violar Virgínia, menina branca que fora punida com esse casamento por sua tia. Desde a noite em que fora estuprada por Ismael não saiu mais da casa e, depois de um tempo, nunca mais saiu do quarto: "Essa primeira noite ficará para sempre marcada pela presença, no quarto do casal, da cama de solteira de Virgínia, quebrada, os lençóis em desordem, o travesseiro no chão" (Lopes, 2007, p. 74).

A personagem Virgínia apresenta muitas oscilações em seu humor, ora ela rejeita Ismael e lhe culpa pelo seu cárcere, ora confirma a versão de Ismael de que ela assim o pedira, até declarar seu amor e seu desejo pelo médico negro. Virgínia vivia com sua tia e quatro primas na casa onde ainda reside com Ismael. A mais nova das primas iria se casar, o noivo em visita apaixonara-se por Virgínia até que certo dia ambos são encontrados aos beijos na sala. Depois de testemunhar tal traição a prima enforca-se e o noivo foge para decepção e ódio da tia. Como vingança a tia vende a casa ao médico da família, Ismael, e permite que ele suba as escadas e viole sua sobrinha, branca e alva e, por fim, realize, segundo a fala de Elias, o desejo de todo homem negro: violar uma mulher branca. Desde essa noite o quarto está intocado e Virgínia já tivera três filhos.

Elias é irmão de criação de Ismael, filho de seu padrasto, um homem branco de origem italiana. Quando criança Ismael trocou o remédio de Elias por ácido deixando-lhe cego. Antes de sair da casa, Ismael culpa sua mãe por ser negro, ela, por sua vez, amaldiçoa o filho. Essa maldição é reiterada por Elias, a pedido dela no seu 
leito de morte. O retorno de Elias marca, não apenas a reiteração da maldição, mas apresenta as características cruéis de Ismael que permite a presença dele na casa e Ihe alerta acerca de Virgínia, proibindo a interação. Ismael afirma que Virgínia é divina e celeste e Elias é da lama interditando o contato de ambos. Contudo, Virgínia acaba sabendo da presença do cunhado e trai Ismael, vindo a nascer dessa relação Ana Maria. Na peça, Ismael com a ajuda de Virgínia mata Elias, aumentando sua lista de crimes.

A tia e as primas são personagens secundários interessantes em cena. Das cinco filhas, apenas a caçula fora destinada ao matrimônio, contudo isso não ocorre. Ao que parece a morte incide nessa família tendo a primeira prima se suicidado e uma segunda morta e estuprada por um maníaco de seis dedos. A tia tem ódio de Virgínia, lembrando as características das madrastas dos contos infantis, é ela quem entrega a sobrinha a Ismael e é ela quem lhe conta que Virgínia o traiu com Elias. As visitas da tia sempre preveem mais mortes dentro da casa mórbida. Há, também, a presença da empregada da casa: Hortênsia e dos coveiros, todos negros.

Jean-Pierre Vernant (2006) afirma que os mitos evocam ritos exigidos por eles, não seria diferente com as maldições que, nas tragédias áticas, perseguem gerações e gerações descritas nas lendas heroicas. O ódio de Ismael por sua cor ultrapassa todas as barreiras, inclusive, ele culpa deus por sua cor e, após, torna-se um deus dentro do recôndito da casa em que vive. Virgínia pede que ele permita a imagem de Jesus Cristo no quarto, Ismael nega a presença de qualquer representação de homem negro. Esse ódio o faz deixar o lar de forma conturbado levando consigo a maldição materna. Como todo mito é preciso de ritos que o tornem "vivo", a maldição materna, também, precisa ser reiterada e o mensageiro responsável por ritualizá-la é Elias.

ELIAS- Você sabe que sua mãe está entrevada?

ISMAEL- Ouvi dizer.

ELIAS- Antes de minha partida, me pediu por tudo...

ISMAEL- Sei.

ELIAS- ... eu jurei que viria dizer apenas estas palavras: "Ismael, tua mãe manda sua maldição!"

ISMAEL- Já deste o recado...

ELIAS- Não é recado. É maldição.

ISMAEL- Seja maldição. Agora, a porta é ali, embora tu não enxergues.

ELIAS- Eu vim para ficar, Ismael.

ISMAEL (com humor sinistro) - E esperas que eu deixe?

ELIAS- Não tenho lugar nenhum para ir.

ISMAEL- Preferes que eu te expulse daqui? Que te leve de rastos? Ou já perdeste o medo?

ELIAS- Tive medo quando era menino. Naquele tempo, você me batia porque eu não era filho de sua mãe, porque era filho de uma mulher branca com homem branco. Mas hoje, não. Talvez amanhã o medo volte. (Rodrigues, 1981, p.130, $1^{\circ}$ quadro do $1^{\circ}$ ato)

Em seu lar, Ismael sabe que detêm de um poder quase divino e, logo, a maldição materna não lhe causa temor. Contudo, percebemos que a maldição atinge o ponto mais frágil da casa: a fidelidade forçada de Virgínia. Esse miasma toma outras e maiores proporções com o nascimento não de um menino, mas de Ana Maria. Talvez a casa sem sol, onde apenas a noite está presente para tomar posse dos seus mo- 
radores seja, também, a perpetuação da maldição materna. Além disso, Ismael não consegue atingir a felicidade e nem mesmo é detentor do amor de Virgínia, o que o leva a criar Ana Maria distante da mãe.

Virgínia ao ser acusada por Ismael pela morte dos meninos, três em oito anos, afirma que fora o destino, eles precisavam morrer. A Tia também alerta, profeticamente, acerca do destino mortuário de Ana Maria para desespero e repúdio de Ismael. Mas é inegável que todos que se envolvem na relação do casal e adentram suas casas, que não eles, acabam sendo amaldiçoados tendo seu caminho direcionado à morte trágica. A morte se faz presente em toda peça, ela, como o suor de Ismael, escorre pelas paredes e está encruada na carne de Virgínia e, sobretudo, na carne dos filhos do casal. Todos estão fadados a ela de forma monstruosa e, como é o objetivo de Nelson Rodrigues, desagradável.

VIRGÍNIA (recuando) - Não odiei teus filhos!

ISMAEL- Odiaste. Antes deles nascerem, quando estavam ainda no teu ventre- tu já os odiava. Porque eram meus filhos... Levanta o rosto! Minto? E porque eram pretos e se pareciam comigo. Tu mesma disseste- que tinham o meu rosto...

VIRGÍNIA (olhando a fisionomia do marido) - Tinham o teu rosto...

ISMAEL- Eles morreram porque eram pretos...

VIRGÍNIA (com terror) - Foi o destino.

ISMAEL (contendo-se ainda) - Porque eram pretos. (novo tom)- Pensas que eu não sei? VIRGÍNIA (recuando, num sopro de voz) - Não, Ismael, não!...

ISMAEL- Que fizeste com meus filhos?

VIRGÍNIA (apavorada) - Nada- não fiz nada...

(Os dois se olham)

ISMAEL- Mataste. (baixa a voz) Assassinaste. (com violência contida) Não foi o destino: foste tu, foram tuas mãos, estas mãos...

(Virgínia, instintivamente, olha e examina as próprias mãos)

ISMAEL- Um por um. Este último, o de hoje, tu mesma o levaste, pela mão. Não the disseste uma palavra dura, não o assustaste; nunca foste tão doce. Junto do tanque, ainda o beijaste; depois, olhaste em torno. Não me viste, lá em cima, te espiando... Então, rápida e prática- já tinhas matado dois- tapaste a boca do meu filho, para que ele não gritasse... Só fugiste quando ele não se mexia mais no fundo do tanque...

VIRGÍNIA (feroz, acusadora) - Então, por que não gritou? Por que não impediu? ISMAEL (cortante) - Mas é verdade?

VIRGÍNIA (espantada) - É.

ISMAEL- Aos outros dois você deu veneno...

VIRGÍNIA (hirta) - Sim.

ISMAEL- Porque eram pretos.

VIRGÍNIA (abandonando-se) - Porque eram pretos. (Com súbita veemência). Mas se sabias, por que não impediste?

ISMAEL (com voz mais grave, mais carregada) - Não impedi porque teus crimes nos uniam ainda mais; e porque meu desejo é maior depois que te sei assassinatrês vezes assassina. Ouviste? (Com uma dor maior)- Assassina na carne dos meus filhos. (Rodrigues, 1981, p. $158-159,1^{\circ}$ quadro do $2^{\circ}$ ato)

A morte dos filhos do casal faz parte sim do destino inexorável que assola a todos, Virgínia percebe a necessidade do sacrifício desses meninos em nome da manutenção da maldição. Ismael que não acredita na maldição materna culpa a esposa, mas é conivente com as três mortes. Essa conivência se dá pelo fato de ter Virgínia como sua igual, pelo menos no ódio contra si mesmo. Cada menino que é sacrificado por Virgínia é uma parte de Ismael que se esvai e, dessa forma, ele se sente menos negro, cada vez mais claro. 
O menino que é velado no início da peça passa por um ritual: de forma doce, ele é levado até o tanque; recebe um beijo de sua mãe e só então é afogado. É no fundo dessas águas mortuárias, levada pelas mãos que Virgínia assassina sob a conivente presença de Ismael, um filho odiado por ambos por um motivo comum: as crianças eram negras. Do caso de Virgínia com Elias é esperado por ela um menino que será amado e que apagará as tristes lembranças de seu casamento, para Ismael, o esperado menino será fruto de sua vingança, contudo quem nasce é Ana Maria. As águas aparecem em Anjo como mortuárias, águas pesadas cuja morte evocada é abrupta e inexorável, mas aguardada e movida pela força do destino.

Carla Souto (2001) afirma que os personagens rodriguianos são seres mutilados e impossibilitados de atingirem a felicidade e, dessa forma, o caminho natural é a tragédia, mas não a tragédia ática com seus elementos e objetivos já não concebidos, nem mesmo tragédia em seu sentido comum. Este caminho trágico é marcado pelo que há de mais cruel, monstruoso e desagradável aos humanos: a morte. Ismael não consegue ser feliz, mesmo com o sucesso em sua carreira e a obtenção de uma fortuna inestimável não conseguirá mudar a cor de sua pele. Virgínia sabe que por mais que fuja da casa de Ismael ele sempre estará em si, entranhado.

Ismael instaura um ritual monstruoso de cegamento: ele assim o faz com Elias e após com Ana Maria ainda criança. Enquanto Gorgó paralisa em seu horror, o "Grande Negro" cega a todos que são brancos com exceção de Virgínia. Ana Maria é cegada por Ismael enquanto bebê em um tétrico e macabro ritual onde ele permite que a menina o observe com atenção, compreendendo sua cor negra para depois cegá-la com ácido. Ana Maria cresce sob os cuidados de Ismael que lhe conta que todos no mundo são negros e apenas ele, seu pai, é branco. Por fim, Ana Maria é trancada por Ismael em um mausoléu de vidro, criado para a morte redentora de Ismael e Ana Maria, o que não ocorre. As mãos de Virgínia e Ismael cumprem, mais uma vez, com o sacrifício de sua prole.

Dos mitos e ritos evocados e reatualizados, a morte ainda jovem se apresenta na peça não apenas nos filhos de Ismael, mas no diálogo entre Virgínia e Elias. Virgínia afirma que se ela morrer é possível que não seja enterrada, logo, não receberá os ritos mortuários. Em troca ela será posta na cama de solteira, sempre quebrada, e terá mais e mais filhos negros. Virgínia, como a grande maioria dos humanos, tem temor à morte.

ELIAS (em pleno sonho) - Você nunca se imaginou morta? (Segura Virgínia pelos dois braços). Eu mesmo- e não ele; ele, não- eu seria capaz de matar você. Sem ódio, sem maldade- por amor; para que ninguém acariciasse você e para que você mesma não deseja-se ninguém- ficasse para sempre com a boca em repouso, os seios em repouso, os quadris quietos, inocentes...

(Elias põe-se de joelhos e, na sua embriaguez, acaricia Virgínia, que de deixa adorar, sem um gesto, petrificada)

ELIAS- Morrer assim não te faria mal- juro! Seria um bem- não compreendes que seria um bem?

VIRGÍNIA (dolorosa) - Compreendo.

ELIAS- Você gostaria... Seria uma coisa tão meiga como a morte de uma menina; não de mulher, mas de menina, no dia da primeira comunhão...

VIRGÍNIA- Ismael sonha com uma morte assim, mais ou menos assim...

ELIAS (doce) - Eu é que deveria ser teu assassino, e não ele- eu!... (Rodrigues, 1981, p. $158,1^{\circ}$ quadro do $2^{\circ}$ ato) 
A embriaguez de Elias ocorre após sua noite orgiástica com Virgínia, logo, ele é tomado pela embriaguez semelhante àquela advinda das Dionísias na Grécia antiga. Além disso, ele também é tomado pelo apolíneo pelo sonho mórbido que apresenta de matar Virgínia e mantê-la eternamente em um leito petrificada. O desejo, mais uma vez, aparece na peça rodriguiana como um sentimento que deve ser purgado. A inocência é um ponto que deve ser mantido e, ainda mais acentuada, no nome da personagem "Virgínia", a virgem casta e pálida que fora, principalmente no romantismo brasileiro, idealizada e posta em um pedestal intransponível.

A família de Ismael não carrega um sobrenome que o liga aos ancestrais ilustres, ao contrário, ele os nega chegando ao ápice de culpar a mãe por ser negro. Se na peça mítica antedente, Álbum de família (1945), a família dos primos Jonas e D. Senhorinha são ilustres por pertencerem a uma família com antepassados também ilustres e na peça posterior, Senhora dos afogados (1947), os Drummond honram seu tradicional sobrenome, em Anjo negro, Ismael é ilustre por ascender socialmente. Tanto ele, quanto Virgínia, não ostentam em seu tymós a família ilustre que compõem, mas compreendem a imponência que os cerca e o torna, de alguma forma, uma família tradicional sob os olhos da sociedade. Mais do que isso, Ismael pensa deter de um poder divino, sendo o deus dentro de seu lar para Virgínia e, sobretudo, para Ana Maria que pensa ser ele o único branco de todo o mundo.

Toda família é composta de laços de afeto, sociais e jurídico-religiosos demarcados pelo casamento, além disso, como afirma André Ruffiot (2011), a família engendra outros mitos e necessita que alguns rituais sejam seguidos para a sua manutenção como, por exemplo, o afago materno antes de dormir e os momentos de diálogo na hora das refeições. Virgínia e Ismael, assim como todas as famílias rodriguianas, não fazem nenhuma refeição juntos e, quiçá, se reúnam para algum diálogo e troca e iniciação de suas experiências. Sem os laços devidamente apertados entre o casal que se odeia, a casa não poderia ser aquele espaço aconchegante e seguro, assim, de todos os espaços da casa, a residência de Ismael e Virgínia encerra-se em um grande porão.

A casa, além da falta de teto, evoca uma noite sem nenhum encanto. Mesmo com altos muros, Ismael não permite que Virgínia saia de seu quarto. Conforme aumenta a "solidão do negro", como indica uma das rubricas do primeiro ato, Virgínia também é isolada. Ela pede para Ismael que lhe permita um passeio pelo jardim para olhar as estrelas, mas Ismael the indica que não há mais estrelas, a noite que invade a casa é, sobretudo, mortuária e triste. Essa mãe não chora seus filhos mortos, ou melhor, os filhos de Ismael, apenas tenta rezar permanecendo imóvel frente a cama do casal.

Ao que parece, a morte dos meninos faz parte da maldição de Ismael e, por sua vez, Ismael faz parte da maldição de Virgínia pelo suicídio da prima virgem. A mãe dos meninos não poderia chorar a morte daqueles que ela mesma matou, sacrificando, por último, este que está sendo velado, afogado. Não podemos esquecer que Virgínia fora sacrificada há oito anos, se não ela em todo seu ser, a menina virgem que está presa na cama de solteira intacta e que vaga no sonho de Elias e Ismael. Essa morte evoca outras ligadas a ela como, por exemplo, a morte de Elias. 
Além dos inúmeros mitos evocados na peça advindos da família e em nome da manutenção dessa família, a maldição que "escorre pelas paredes" e toma conta da casa e de seus moradores é reatualizada pela presença de "quatro" figuras como afirma a rubrica: a tia e as primas, esse erro da rubrica pode enganar aos leitores menos avisados, mas na verdade é um erro, pois no programa de estreia da peça há a presença de quatro atrizes (Nieta Junqueira; Rosely Mendes; Yara Brasil e Aurora La Bella). Essas primas são todas virgens e, conforme passa o tempo, vão enlouquecendo. Elas estavam presentes na noite em que Virgínia fora estuprada por Ismael como forma de punição da tia, após elas retornam nos funerais dos filhos do casal.

O retorno da tia e das primas marca a reatualização dessa maldição e punição pelo maior pecado na cultura judaico-cristã: o suicídio. No funeral desse terceiro "anjo negro" as primas e a tia chegam atrasadas e no silêncio da casa imaginam que todos estão no cemitério. A chegada da tia marca, quase sempre, o caos e a ruptura de qualquer possibilidade de equilíbrio na família. A cada morte dos filhos de Ismael, momento em que ele também morre, a presença da tia evoca mais dor e mais morte.

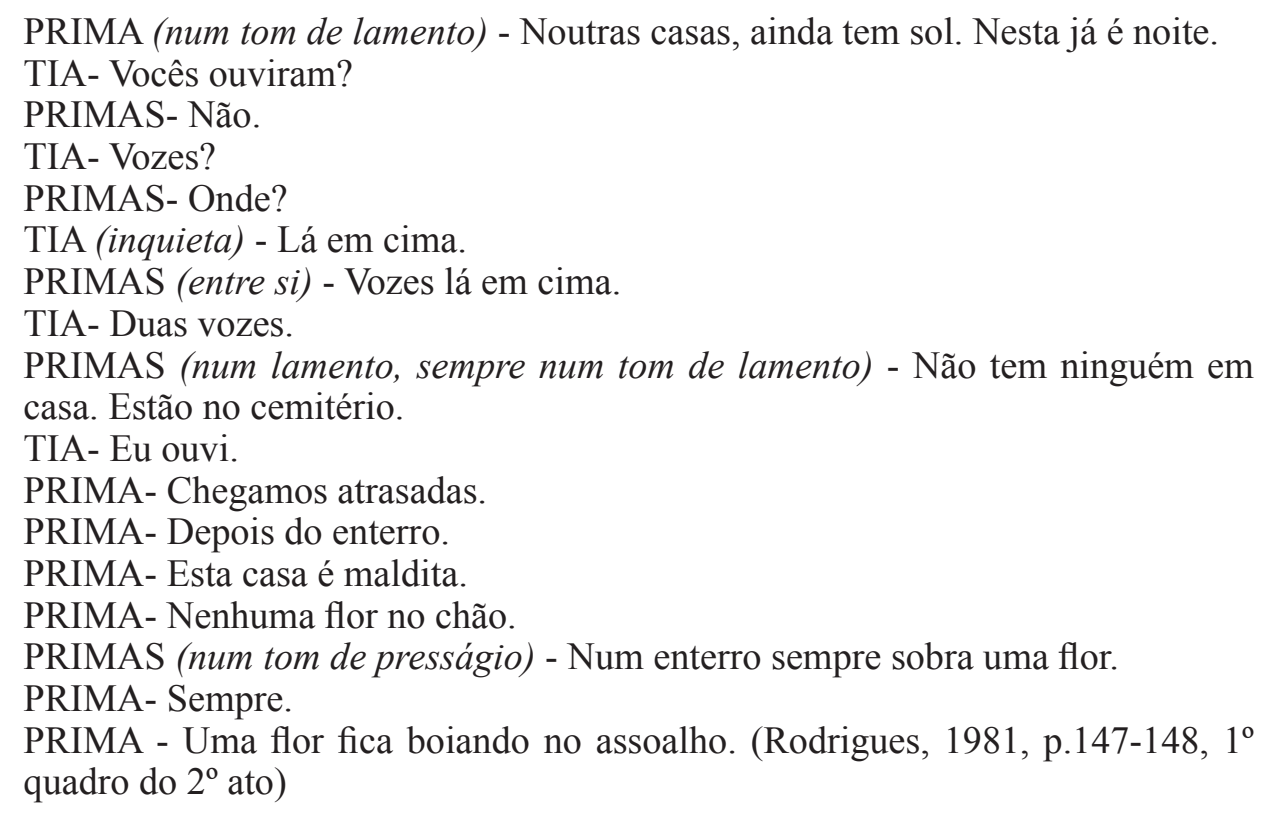

A fala da prima marca, novamente, o negrume que envolve essa casa sem telhados e essa noite sem estrelas. A maldição de ambos é simbolizada por esse breu total da casa murada e em ruínas. As primas, ao que indica a tia posteriormente, trazem a loucura na carne, mas como todas as personagens desequilibradas rodriguianas apresentam momentos de lucidez. Um deles é a reiteração da casa maldita e a falta de vida que escorre pelas paredes, as flores não sobrevivem, nem mesmo as de plástico que não morrem. Uma das primas reflete sobre essa falta de flor, enquanto outra profetiza que sempre sobra uma flor após os ritos fúnebres. As flores simbolizam a dor e a saudade do morto, utilizada nos rituais sacrificiais em forma de coroa para afastar a morte. Na cultura judaico-cristã evocam a dor deixada e a esperança da entrada do morto no paraíso. As coroas de flores, ainda presentes nos funerais da nossa cultura, trazem além das flores mensagens que expressam a saudade do morto. 
Após o nascimento de Ana Maria, quinze anos da morte do terceiro filho do casal, a tia retorna a casa trazendo o luto e a desgraça sob seus ombros. Desta vez a desgraça recai sobre a própria tia. As primas morreram todas virgens, com exceção de uma que fora estuprada pelo maníaco de seis dedos. Ao que a tia indica que o estupro era permitido para que a filha não morresse virgem, mas não era preciso assassiná-la. Ao final a tia aumenta a cota de maldição sob a casa: "Tua filha morrerá, Virgínia [...]. E VIRGEM! (Rodrigues, 1981, p.179, 2ㅇ quadro do 3ㅇa).

Além de amaldiçoar Ana Maria com sua morte e, sobretudo, virgem, a tia encerra suas pragas dedicando a Virgínia que fosse consumida pelo seu desejo. Tanto desejo ardente que após a morte da sobrinha não fosse possível atar seus pés para que as pernas ficassem juntas e, dessa forma, sendo enterrada de pernas abertas evocando mais desejo. A relação dessa tia com Virgínia é mantida pelo ódio de uma pela outra e, dessa forma, não teria como acabar de forma menos cruel e desagradável. 0 primeiro diálogo entre elas já mostra o ódio contra as simulações de Virgínia.

TIA (arrumando a cama e para Virgínia) - Você não diz nada?

VIRGÍNIA (ficando de costas para a tia e de frente para a plateia) - NADA!

TIA - Quando eu subi, um homem vinha descendo a escada...

VIRGÍNA (rápida) - Meu cunhado.

TIA - Cego.

VIRGÍNIA (confirmando) - Cego

TIA- E é só teu cunhado?

VIRGÍNIA - Só.

TIA - Juras?

VIRGÍNIA - Juro.

TIA - Pelo teu filho que foi enterrado hoje?

(Por um momento Virgínia hesita; vira-se, fica de frente para a tia e de costa para a plateia; estão, rosto com rosto.)

VIRGÍNIA- Pelo meu filho...

TIA (numa fúria controlada) - Por que mentes?

VIRGÍNIA (dolorosa) - Não minto!

TIA- Por que dissimulas? Por que escondes sempre a verdade? - Desde menina... VIRGÍNIA- Jurei!

TIA- Que vale teu juramento? (Sem transição) Ele entrou no teu quarto?

VIRGINIA- Não!

TIA- Entrou!

VIRGÍNIA- Veio só falar comigo. Ficou no corredor...

TIA-Cínica! Eu sei que ele entrou, que ficou aqui muito tempo!...

VIRGÍNIA (rápido) - Se sabe- por que me atormenta com perguntas? Queria tanto ficar sozinha, para rezar...

TIA (para si mesma, num transporte) - Graças, meu Deus, por ter chegado atrasada! Se não fosse isso, talvez não soubesse nunca que tens um amante... (Rodrigues, 1981 , p. $152-153,1^{\circ}$ quadro do $2^{\circ}$ ato)

A tia acredita que a morte dos filhos de Virgínia lhe causa dor e sofrimento e, portanto, fazem parte da punição por ela elencada. Afinal, e ainda cremos, que a morte de um filho é para uma mãe dor cruciante, contudo os filhos que morrem não pertencem a Virgínia, como ela afirma, são filhos de Ismael. Nem mesmo Ana Maria é filha de Virgínia é de Elias, filha que por obra do destino deveria ser sua salvação se nascesse menino. A tia afirma que Virgínia mente, esconde e dissimula desde menina, o que corrobora para discorrermos acerca das madrastas dos contos 
de fada. Mas a relação da tia com Virgínia escorre o mesmo ódio e o mesmo embate que ela tem com Ana Maria.

A relação de mãe e filha, como em outras peças rodriguianas, é de caos e ódio. Virgínia passa três noites (como se houvesse dia na casa) conversando com Ana Maria sobre o desejo sexual. A mãe tenta convencer a filha de fugir e amar puramente como só as prostitutas o sabem, ao passo que encerrando seu tempo percebe que a filha é sua maior inimiga e, já deflorada por Ismael, não abandonará o quarto. Virgínia reconhece: "Você sempre foi minha inimiga" (Rodrigues, 1981, p. 186, 2ำ quadro do 3ำ ato).

ELIAS (pedindo) - Fique perto de mim.

VIRGÍNIA (doce) - Fico, sim. (Muda de tom). Todos ali me odiavam. Porque eu tinha quinze anos, era bonita demais- linda! Vivia cercada de olhos. Quando eu me vestia, vinham-me espiar. Foi aí que Ismael apareceu, primeiro como médico, depois como amigo também. "Preto, mas muito distinto", diziam; e, depois, doutor. Em lugar de interior, isso é muito. Ele se apaixonou por mim...

ELIAS (doce e inquieto) - E você por ele, não?

VIRGÍNIA- Juro que não. Juro por tudo. Eu já tinha medo do desejo que havia nos seus olhos. Já adivinhava que amor com um homem assim é o mesmo que ser violada todos os dias. (Rodrigues, 1981, p. 143, $2^{\circ}$ quadro do $1^{\circ}$ ato)

Elias afirma que o desejo de Ismael sempre fora violar uma mulher branca, desejo que Virgínia já previa em seus olhos. Trancada em seu quarto recebendo a visita apenas do marido e da empregada Hortênsia, Virgínia pede a Ismael que permita o quadro de um rosto que ela lembrara: o rosto de um Cristo. O marido negro não permitiu, de forma alguma, a presença de um rosto branco no quarto do casal, mas talvez permitisse a presença se o Cristo fosse cego. Na rubrica, Nelson Rodrigues caracteriza Elias como um homem branco, de cabelos louros anelados e cujo rosto expressa uma doçura "quase feminina". Essa cegueira "divina" corrobora para a afirmação de que o desejo se encontra no olhar dos homens, desejo que Virgínia repudia. Mesmo proibindo a presença do Cristo cego no quarto ele se faz presente na peça e é responsável pela ruptura da solidão de Virgínia. Elias desempenha o papel desse Cristo cego, contudo a purificação pelo sexo esperada por Virgínia não ocorre sendo posto em seu lugar a maldição do próprio Elias.

Além disso, a morte dos três filhos também é incitada pelo olhar dos meninos. Virgínia afirma que os olhos dos meninos se parecem muito com os olhos do pai e que parece que Ismael a está monitorando todo o tempo. Ela afirma para Ismael, ao ser encontrada na mesma posição desde a morte do terceiro anjo, que: "Esperava você! Só posso esperar você, sempre. Só você chega, só você parte. O mundo está reduzido a nós dois- eu e você" (Rodrigues, 1981, p.132, 1ำ quadro do 1ำ ato). O rosto dos meninos é o mesmo de Ismael, rosto este que a fez esquecer todos os outros rostos, ou seja, Ismael é deus, apenas seu rosto existe nesse mundo. Se o rosto é de Ismael, os olhos que causam terror em Virgínia são os mesmos do marido e, talvez, lhe façam recordar do desejo animalesco do "doutor" negro.

Virgínia convence Ismael que lhe ama, contando acerca de uma visão que teve quando menina de quatros negros carregando um piano. Nelson Rodrigues já havia falado desses personagens quando o corpo da prima estuprada e morta ia sendo levado. Ele afirma que esses quatro negros são os mesmo do primeiro ato, responsáveis por 
carregar o caixão do menino negro. O dramaturgo, ainda, caricatura esses personagens descrevendo-os nus da cintura para cima, de calças arregaçadas, chapéu de palha e charuto na boca, afirmando na rubrica que antecede a visita da tia que: "Os negros falam com um acento de nortistas brasileiros, mas os gritos lembram certos pretos do Mississipi que aparecem no cinema" (Rodrigues, 1981, p. 176, 1ำ quadro do 3으으.

\footnotetext{
VIRGÍNIA (fora do tempo) - Quando me tapaste a boca- na primeira noite- sabes de que é que me lembrei? Apesar de todo o meu terror? (Deslumbrada). Me lembrei de quatro pretos, que eu vi, no Norte, quando tinha 5 anos- carregando piano, no meio da rua.... Eles carregavam o piano e cantavam.... Até hoje, ainda os vejo e ouço, como se estivessem na minha frente... Eu não sabia por que esta imagem surgia tão viva em $\mathrm{mim}$ ! Mas agora sei. (Baixa a voz, na confidência absoluta). Hoje creio que foi esse o meu primeiro desejo, o primeiro. (Rodrigues, 1981, p. $189,2^{\circ}$ quadro do $3^{\circ}$ ato)
}

As quatro figuras negras que aparecem na peça sempre antecedem a morte de alguém da família. Ao que parece foram eles, contratados por Ismael, que carregaram as quatro alças dos pequenos caixões brancos "de anjo", eles carregam em um lençol o corpo sem vida da prima de Virgínia que, diferente das outras, não morre virgem. Não sabemos, ao certo, se Virgínia realmente viu e desejou, pela primeira vez, os quatro negros carregando o "piano" que mais parece os caixões dos meninos quando criança ou, então, utiliza a presença mortuária dos negros para enganar Ismael. A afirmação do primeiro desejo nos faz recordar do "pecado original" que está internalizado em todos nós e que é o interdito do desejo sexual.

A família, na perspectiva de Ruffiot (2011), é o grande "caldeirão" onde nascem a vida, o prazer, o desejo e a lei, logo, espaço onde compreendemos e apreendemos os interditos, bem como as fases do prazer e o desejo. Ismael e Virgínia negam toda sua ancestralidade. Ismael, como afirma Elias, é um homem maldito por culpar a própria mãe de ser negro, por sua vez, Virgínia nutre um ódio recíproco com o único filamento de família que possui: a tia e as primas. Talvez a falta de antepassados que legitimem a origem ilustre de cada um não permita que o casal garante sua continuidade. Virgínia está correta ao culpar o destino pela morte dos filhos, eles precisam ser sacrificados e a cada morte Ismael se vê também morto. Não podemos esquecer que a morte traz consigo uma palidez, já presente em Virgínia, que Ismael tanto busca na negação de sua cor.

Virgínia sente que o suor de Ismael não está apenas nas paredes da casa, mas que já estão entranhados em sua pele e mesmo que fuja ele sempre fará parte dela. No diálogo com Elias afirma e questiona o irmão branco do marido: "Quem ama mistura suor com suor. (Pergunta, com avidez). Diga se o suor dele ficou em mim, se está em minha carne? Ou se é imaginação minha?" (Rodrigues, 1981, p. 142, 2 quadro do 1을 ato). Elias afirma que não, que é sua imaginação, mas Virgínia sabe a resposta e nega a proposta de fuga de Elias, afirmando que: "Se eu fugisse, a transpiração dele não me largaria; está entranhada na minha carne, na minha alma. Nunca poderei me libertar! Nem a morte seria uma fuga!" (Rodrigues, 1981, p.145, 2ㅇ quadro do 1ㅇa).

A primeira rubrica que apresenta o cenário da peça apresenta o coro das Senhoras sentadas em semicírculo o que nos faz lembrar o coro das tragédias áticas dispostos na orquestra, semicírculo cujo meio representava a presença de Dioniso. Nelson Rodrigues indica um número de dez senhoras, contudo o programa da peça apresenta apenas seis. 
Esse coro é marcado pelas incessantes orações que fazem ao longo da peça, dando uma pequena leveza nas monstruosidades ocorridas pelas mãos do casal. Elas marcam o que há de sagrado, suavizando, na medida do possível, o embate monstruoso do casal.

Esse coro profético de senhoras negras de pés descalços em semicírculo é o oposto do casal. Enquanto Ismael e Virgínia repudiam qualquer presença divina, mais Ismael do que Virgínia, o coro está sempre em oração, murmurando, clamando e buscando o sagrado. Nesse sentido, o dramaturgo apresenta uma oposição entre sagrado e profano. Ismael é, segundo a fala de Elias, um homem maldito por repudiar sua cor e sua ancestralidade. Essa maldição é agravada por Ismael culpar a sua mãe e a Deus, nutrindo seu ódio contra si e contra todos. Virgínia é maldita por carregar em suas costas a culpa do suicídio da prima e, ainda mais pecaminosa, pela ruptura do mito do amor materno, sacrificando seus filhos e Ana Maria em face ao desejo. Enquanto o coro ora "ave-marias e padres-nossos", clamando ao divino pelo fim da escuridão que toma a casa.

Apesar de apresentar uma uniformidade, o coro formado por Senhoras "pretas" apresenta sentimentos difusos em relação aos moradores da casa sem teto. Elas iniciam a peça situando os espectadores acerca dos fatos ocorridos, em especial, o caixão de "anjo" cercado de quatro círios e carregado pelos coveiros negros. Em certos momentos a história do menino velado na casa do médico Ismael confunde-se com a sua infância, o que não é estranho, afinal Virgínia afirma que os filhos negros nascidos de seu ventre não são seus, mas de Ismael.

SENHORA (doce) - Um menino tão forte e tão lindo!

SENHORA (patética) - De repente morreu!

SENHORA (doce) - Moreninho, moreninho!

SENHORA- Moreno, não. Não era moreno.

SENHORA- Mulatinho disfarçado!

SENHORA (polêmica) - Preto!

SENHORA (polêmica) - Moreno!

SENHORA (polêmica) - Mulato!

SENHORA (em pânico) - Meu Deus do Céu, tenho medo de preto! Tenho medo, tenho medo!

SENHORA (enamorada) - Menino tão meigo, educado, triste!

SENHORA (encantada) - Sabia que ia morrer, chamou a morte!

SENHORA ( na sua dor) - É o terceiro que morre. Aqui nenhum se cria!

SENHORA (num lamento) - Nenhum menino se cria!

SENHORA- Três já morreram. Com a mesma idade. Má vontade de Deus!

SENHORA- Dos anjos, má vontade dos anjos!

SENHORA- Ou é o ventre da mãe que não presta!

SENHORA (acusadora) - Mulher branca, de útero negro!

SENHORA (num lamento) - Deus gosta das crianças. Mata as criancinhas! Morrem tantos meninos!

TODAS- Ave-maria, cheia de graça... (perde-se a oração num lamento ininteligivel) Padre-nosso que estais no céu... (perde- o resto num murmúrio ininteligível)

SENHORA (assustada) - E se afogou num tanque tão raso!

SENHORA- Ninguém viu!

SENHORA- Ou quem sabe se foi suicídio?

SENHORA (gritando) - Criança não se mata! Criança não se mata!

SENHORA (doce) - Mas seria tão bonito que um menino se matasse!

SENHORA- O preto desejou a branca!

SENHORA (gritando) - Oh! Deus mata todos os desejos!

SENHORA (num lamento) - A branca também desejou o preto!

TODAS- Maldita seja a vida, maldito seja o amor! (Rodrigues, 1981, p. 125-126, $1^{\circ}$ quadro do $1^{\circ}$ ato) 
O coro não consegue compreender como uma criança que nascera tão forte morre tão de repente. As mulheres discutem acerca da cor do menino, afirmando ser ele moreno, mulatinho disfarçado e, por fim, preto, cor que causa pavor e alvoroço ao coro formado de mulheres negras. Nelson Rodrigues deixa claro que a peça abrange o racismo mais monstruoso que há: o do negro contra si mesmo. Pelas informações dadas pelo coro esse é o terceiro filho do casal que morre e ao que parece essas crianças já trazem a morte nos olhos e seu destino trágico. Outra informação importante é a idade em que os meninos são sacrificados pelas mãos da mãe que é sempre na mesma idade, ou seja, um ciclo que se fecha na mesma época, o que demarca os ritos sacrificiais.

Em Anjo negro aparece pela primeira vez um elemento que marca as peças míticas: as águas pesadas. Este elemento simbólico aparece logo no início da peça na fala do coro que, atônito com a morte, levanta a possibilidade de suicídio, ao que outra senhora afirma que "criança não se mata". A frase escolhida pelo dramaturgo traz dois significados. O primeiro em resposta ao suicídio do menino, mesmo que ele apresente a tristeza em seus olhos e que tenha chamado a morte. O segundo reforça o mito do amor materno e a importância da criança no círculo familiar afirmando que é um interdito matar uma criança dotada de tanta vida. O afogamento desse terceiro menino em águas tão rasas do tanque revela que essas águas são, em seu teor, águas negras e pesadas, águas mortuárias.

\author{
SENHORA- Água assassina! \\ SENHORA- Que parece inocente! \\ SENHORA- Matou uma criança! \\ SENHORA- Oh, Deus, fazei vir um filho branco! \\ SENHORA- Clarinho! \\ SENHORA- Que não morra como os outros! \\ SENHORA- E ninguém diz que este tanque já matou um. \\ SENHORA- Ou mais de um. \\ SENHORA- Ninguém diz. \\ SENHORA- Perdoai, meu Deus, esta água fria e escura!
}

SENHORA- E fazei vir um filho branco, não moreno, mas clarinho, clarinho (Rodrigues, 1981, p. 162, $1^{\circ}$ quadro do $2^{\circ}$ ato)

Ainda em torno do tanque, as senhoras olham as rasas águas, uma água que parece inocente, mas que na verdade já matou uma criança ou mais de uma. O tanque lembra, também, os alteres gregos dedicados aos deuses ctônicos de forma circular e com um pequeno buraco no meio para que o sangue sacrificial escorresse ao centro da terra. Além disso, essa interferência do coro, que ocorre após Ismael saber da traição da esposa, também evoca pensarmos que ele é a representação do útero de Virgínia, afinal em águas tão rasas, profundas, aparentemente inocentes são negras e mortuárias, bem como a afirmação de Virgínia sobre ter outro filho com Ismael e sentir que ele apodrece em seu ventre. Ao redor do tanque elas clamam ao divino perdão pela presença de uma água tão "fria e escura" e clamam a vinda de um filho branco, redenção de Virgínia e, talvez, do casal. 
SENHORA- Graças a Deus, Todo-poderoso...

SENHORA- Há 15 anos nasceu uma filha.

SENHORA- E branca.

SENHORA- Não um menino, mas uma menina.

SENHORA- De peito claro.

SENHORA- Nasceu nua, e por isso o pai logo disse: "É menina".

SENHORA- Porque nasceu nua.

SENHORAS (em conjunto)- Virgem Maria... Maria Santíssima...

SENHORA- Há 16 anos que não faz sol nesta casa. Há 16 anos que é noite.

SENHORA- As estrelas fugiram.

SENHORA- A menina viveu, hoje é mulher.

SENHORA- Hoje é mulher.

SENHORA- Oh, Deus! Poupai Ana Maria do desejo dos homens, e da obscenidade dos bêbados... Poupai Ana Maria dos homens solitários que, por isso, desejam mais!... SENHORA- E não saiu mais enterro.

SENHORA- Sem flor.

SENHORA- Daqui não saiu... (Rodrigues, 1981 , p. 169-170, $1^{\circ}$ quadro do $3^{\circ}$ ato)

Além de situar o espectador acerca dos acontecimentos nesse lapso de quinze anos, o coro nos dá a proporção de quando a casa fora tomada pela escuridão da noite sem estrelas. A peça inicia após oito anos do estupro de Virgínia. Nesse tempo três meninos nascem da união forçada do casal e todos morrem quando atingem certa idade, a mesma idade e o mesmo final de ciclo. Contudo, a escuridão da casa não inicia na noite em que a tia punira a sobrinha, mas um ano antes da vinda de Elias o que soma dezesseis anos. Ou seja, a maldição instalara-se no lar de Ismael e Virgínia com a morte do terceiro filho que também representa a terceira chance de redenção perante deus. Nelson Rodrigues, além das fontes já citadas, reatualiza e mantêm intertexto com a bíblia e essas três negações lembram, além da tripla divindade (deus-pai, deus-filho e deus-espírito-santo), a passagem em que Pedro, o primeiro Papa da Igreja Católica Apostólica Romana, nega Cristo por três vezes. O número três também representa, a partir dos estudos da cabala, a terceira figura presente na criação além de Adão e Eva, a serpente, tema da última peça do dramaturgo.

O coro, como nas outras interposições, clama ao divino que afaste e termine com o desejo, causador de todo caos e desordem na peça, contudo, já situam os espectadores acerca da virgindade de Ana Maria. Ela não é mais "menina" já é "mulher", afirmação que se confirmará no diálogo entre mãe e filha e na ruptura da maldição familiar de morrer virgem. Essa intercessão do coro é tardia, já que Ismael, ainda mais dotado de um poder divino, desposara a filha de Virgínia e Elias após tê-la cegado quando criança. O coro, ainda clama para Ana Maria seja liberta do desejo dos homens solitários e a obscenidade dos bêbados, contudo, mesmo sem os olhos para desejar, a cor alva de sua pele instiga seu padrasto cujo desejo sempre foi violar uma branca, Ana Maria é sua segunda branca. A filha que nascera é tirada dos braços de Virgínia e criada em um quarto, quarto esse que ela crê ser seu mundo, além disso, Ismael lhe conta que todos são negros, inclusive Virgínia, e que apenas ele é branco. Ao final, Ana Maria não consegue vencer o elo de ódio e desejo que há entre Ismael e Virgínia e tem o mesmo fim dos filhos do casal. 
SENHORA- Ó branca Virgínia!

SENHORA (rápido)- Mãe de pouco amor!

SENHORA- Vossos quadris já descansam!

SENHORA- Em vosso ventre existe um novo filho!

SENHORA- Ainda não é carne, ainda não tem cor!

SENHORA- Futuro anjo negro que morrerá como os outros!

SENHORA- Que matareis com vossas mãos!

SENHORA- Ó Virgínia, Ismael!

SENHORA- (com voz de contralto)- Vosso amor, vosso ódio não têm fim neste mundo! SENHORA (grave e lento)- Branca Virgínia...

SENHORA (grave e lento)- Negro Ismael... (Rodrigues, 1981, p. 191-192, $2^{\circ}$ quadro do $3^{\circ}$ ato)

O coro encerrará a peça marcando o reinício do ciclo trágico dos filhos do casal. A intervenção divina do coro conseguiu fazer com que a morte fosse afastada durante quinze anos, contudo a possibilidade de redenção dada ao casal, tal como outras, não surte efeito e eles enveredam pelo caminho desagradável. Com a oportunidade de ser, dessa vez, uma família e nutrir os laços de amor entre seus membros, Ismael escolhe, novamente, ser deus dentro da casa sem teto. Ele retira Ana Maria dos braços maternos, a coloca em outro quarto e a faz acreditar que este quarto é o mundo e que não há nada fora dele. Ainda criança cega a filha branca de seu irmão de criação com sua esposa branca. Virgínia tenta, por três noites, convencer a filha da verdade do mundo e, acima de tudo, despertar o desejo da filha. Contudo, Ana Maria fora cegada por Ismael em todos os sentidos e, por fim, Virgínia percebe que sua filha é, na verdade, sua rival pelo amor de Ismael.

O ápice da queda de Ismael ocorre junto à peripécia, momento, também, que marca o reinício do ciclo trágico de vida e morte em que um novo filho está sendo gerado no ventre de Virgínia e, desde o momento da fecundação, está fadado a morrer. Ismael está pronto para se entregar à eternidade ao lado de Ana Maria, o mausoléu de vidro está posto no pátio esperando os dois amantes. Virgínia tenta convencer a filha do mundo que a espera, contudo ela está inclinada a crer apenas em Ismael, sua única companhia em quinze anos. Nesse momento Virgínia declara seu amor e desejo a Ismael e acaba com a ilusão que ele nutre: o amor eterno de Ana Maria, cuja virgindade já fora corrompida por Ismael.

ISMAEL- Não sabes ainda? Ana Maria não te contou?

VIRGÍNIA- Contou, sim! (colando-se mais a Ismael) Mas ela é criança, é pura e inocente como o pai... E não te ama! Não viu nunca os carregadores de piano.

ISMAEL- Não? (exultante) Se ouvisse o que ela me disse- verdadeiras loucuras, como se eu fosse Deus...

VIRGÍNIA (escarnecendo)- E pensa que você é branco, louro! (triunfante) Se ela soubesse que és preto!... (muda de tom) Ela te ama porque acha que és o único branco... Ama um homem que não é você, que nunca existiu... Se ela visse você como eu vejo- se soubesse que o preto é você (riferozmente) e os outros não; se visse seus beiços, assim como são, ela te trocaria, até, por esse homem de seis dedos...

(Agarra-se mais ao marido, envolve-o)

VIRGÍNIA- Agora, eu não!... Eu te quero preto, e se soubesses como te acho belo, assim como os carregadores de piano!... De pés descalços, cantando!

ISMAEL- És meiga como uma prostituta!

VIRGÍNIA- Sou, não sou? 
ISMAEL (apaixonado)- E ela, não! (com rancor) Ela se dá como o pai possuíacom tanta pureza!... (exalta-se) Não seria com tu... Não teria o medo que sempre tiveste... Não gritaria... Ama sem sofrimento e sem pavor... E não sabe que eu sou preto (tem um riso soluçante) não sabe que sou um "negro hediondo", como uma vez me chamaram... Só me ama porque eu menti- tudo o que eu disse a ela é mentira, tudo, nada é verdade! (possesso) Não é a mim que ela ama, mas a um branco maldito que nunca existiu!

VIRGÍNIA- Vem comigo, vem!

ISMAEL (espantado)- Mas e ela? Você não compreende que ela não deixa? Que estará sempre entre nós?

VIRGÍNIA- Eu sei como fazer- para que ela fique tranquila... (resoluta) Vai chamar minha filha. Traz minha filha. Diz que é um passeio. E quando ela chegar aqui, eu quero que tu a beijes como eu fiz com teu filho que morreu, no tanque... (Rodrigues, 1981, p. 189-190, $2^{\circ}$ quadro do $3^{\circ}$ ato)

Ismael estava determinado a seguir sua vida ao lado de Ana Maria, permitindo que Virgínia fugisse. Mas Virgínia não consegue fugir, essa alternativa já havia sido posta a ela feita por Elias, o suor de Ismael está encruado dentro dela. O coro deixa claro, desde o início da peça, que o desejo que assola e amaldiçoa o casal não parte apenas de Ismael, mas também de Virgínia que deseja o médico negro. Ao que tudo indica os laços de ódio e desejo entre o casal serão rompidos pela pureza de Ana Maria, contudo, ao reconhecer-se negro e mortal, Ismael muda seus planos e reinicia o ciclo dos anjos negros. O médico negro acredita que encontrará a felicidade ao lado de Ana Maria, que será pleno tal qual deus, mas Virgínia quebra seu encanto e, em seu reconhecimento, opera a peripécia aos moldes das tragédias áticas.

A figura do suor, trocado no ato sexual, que marca a carne de Virgínia e está presente na casa sem teto, também representa nessa passagem a fortuna que Ismael juntara como médico. Ismael não desprezara apenas sua cor, sua raça, a vida dada por deus, mas no desejo cego de casar-se com uma branca ele nega a sua riqueza, isolando-se na casa junto a Virgínia. Ela sabe que é um homem maldito por suas escolhas, ela sabe que a traição de Virgínia com seu irmão Ismael é parte de sua punição. Ismael está em queda e é consciente de ser merecedor dessa punição divina.

Contudo, mesmo consciente da queda trágica que carrega qualquer possibilidade de ter uma família, Ismael busca a plenitude ousando de poderes divinos que pensa ter. Ele afirma que a prisão de Virgínia não fora ideia dele, mas dela na noite em que a violara, mas o fato de prendê-la sucessivamente, na casa e no quarto do casal marca sua superioridade. Virgínia afirma que é submissa a Ismael diante de Ana Maria, talvez porque sua tentativa de fuga e redenção acabara na morte de Elias ou que em conversa com o cunhado reconhecera ser impossível fugir das marcas que carrega. Ainda, Ismael ser dotado do direito de retirar Ana Maria dos braços de Virgínia; ela a cria como mulher, como um animal a ser sacrificado na mesa que movimenta o ódio e que mantêm os laços com a esposa branca; ele a cega em um ritual macabro; cria e concebe um mundo fechado dentro do quarto, mundo em que ele é o único branco e por fim, junto a Virgínia, ele a entrega à morte.

Ismael não é deus, nem portador do destino dos filhos, nem ele, nem Virgínia. Contudo, a cada possibilidade de redenção de todos os crimes, pecados e monstruosidades ele se porta de mais força e mais poder. Sua constante queda, consciente de toda maldição que assola a casa, é marcada por mais desmedidas que aceleram a 
queda trágica. A casa se rompe a cada dia que passa, a família está, mais uma vez, no centro dessa queda trágica e mesmo frente as inúmeras tentativas de sacralização, Ismael e Virgínia decidem manter a roda mortuária que gera e mata os filhos nascidos do ventre negro e maldito de Virgínia e, sobretudo, do suor maldito de Ismael.

Essa cama de solteira se concebe como um marco dentro da casa, memória para Ismael da realização de seu maior desejo: ter violado uma mulher branca; já para Virgínia a cama quebrada lembra seu fim, seu esvaziamento, a morte da menina que ela era. O lençol está caído, marcando, talvez, o fim da virgindade da menina Virgínia e, sobretudo, o sangue derramado na noite cruel. O travesseiro está no chão, caído, marcando a violência do ato e a resistência da esposa contra o desejo do médico da família, posteriormente seu marido. Mas o que marca a ruptura do laço de Ismael e Virgínia com o divino são os estilhaços de um crucifixo de cristal partido na noite do crime. O desejo de Ismael desencadeou um processo de rupturas e quedas que não finda nunca e a cada nova ruptura engendra outras cada vez mais monstruosas e desagradáveis.

VIRGÍNIA (indicando a cama) - Ninguém mais dormiu ali... A cama ficou como estava; não mudaram o lençol, não apanharam o travesseiro, nem o crucifixo de cristal, que se partiu naquela noite... Tudo como há 8 anos... Ismael não quer que eu, nem ninguém, mexa em nada... Depois, veio a outra cama, de casal. Mas a minha, de solteira, continua, sempre, sempre... E continuará, depois da minha morte. (Rodrigues, 1981, p. $144,2^{\circ}$ quadro do $1^{\circ}$ ato)

A marca de seu estupro, ainda jovem, não sairá nunca de sua mente, marcado com tal violência que nem mesmo sua morte poderá apagar essa cicatriz. Em contraposição Virgínia, ao trair Ismael com Elias, refaz a cena petrificada da cama de solteira na cama de casal, com a diferença de que nessa cama a tia interfere na disposição dos lençóis e recolhe do chão o travesseiro. A presença dessa cama evoca uma morte, como aquelas ocorridas em rituais de iniciação, já que Virgínia não voltará a ser a mesma. O primeiro sentimento que assola a personagem é a vergonha, como se estivesse suja, aceitando sem resistência a prisão que Ismael propõe. Outro ponto que marca essa morte é que Virgínia nunca mais foi vista, recebendo a visita apenas de sua tia e primas em datas específicas que marcam outras mortes: seu casamento, os funerais dos meninos e na morte de uma das primas após ser estuprada.

Além disso, portadora de um ódio entranhado em seu ser, cuja origem é Ismael, Virgínia porta em sua carne a loucura. As primas, após o suicídio da irmã caçula, acabam enlouquecendo e desenvolvendo uma atração pelas flores do velório. Interessante notarmos que as flores marcam o casamento que elas nunca tiveram e também a morte que as puxa, ou seja, as flores são elementos que marcam os momentos mortuários e Nelson Rodrigues vê o casamento como mortuário e, acima de tudo, essas famílias ilustres que escondem seu verdadeiro ser. Quem percebe e questiona a loucura de Virgínia é Ana Maria no diálogo, ou embate, de três noites, ao que Virgínia não aceita.

A morte está nas mãos, são elas que desencadeiam a morte sacrificial, é das mãos do sacerdote elencado pelo povo que o machado desce em um só golpe no pescoço do animal e, em sacrifícios a deuses considerados estrangeiros pelos gregos, 
são as mãos que portam a faca que degola o estrangeiro. As mãos, em Anjo negro, portam a força da morte, e Virgínia, tal como o ato de Medeia, é incumbida de matar todos os seres que nascem de seu ventre, um a um ela os entrega a morte, apenas Ana Maria não é sacrificada com a mesma idade dos meninos. O sacrifício da filha de Virgínia e Elias, diferente dos filhos de Ismael, é necessária mais pulsão mortuária e ela ocorre por quatros mãos: as de Virgínia e as de Ismael.

O que resta de Ana Maria é apenas um grito silencioso, como aquele que George Steiner (2006) conta na conclusão e que abre espaço para a possibilidade de sobrevivência da tragédia. Grito silencioso, tal como aquele do filho em Mãe coragem e seus filhos (1941) de Brecht, se repete em Anjo negro, encerrando a peça, mas reinicia o ciclo de morte dos filhos de Ismael. Virgínia, ao se declarar a Ismael, afirma que Ana Maria não saberá amar Ismael por sua inocência, o que reitera a acusação do coro no início da peça de que ela desejou o médico negro e a acusação da tia de que Virgínia é cínica. O cinismo da personagem chega ao seu ápice no confronto com a filha e as inúmeras tentativas de levá-la a fugir em seu lugar, afinal o veredicto de Ismael após a conversa de três noites fora a expulsão de Virgínia.

ANA MARIA- Não importa que tu, um dia, tenhas chamado um cego... Tenhas feito esse cego subir a escada e, depois, entrar no teu quarto... Eu escolhi outro pai... Ele é o Noivo... claro, alvo... Eu sinto quando ele vem, quando ele está... Sinto a presença dele como um coração batendo dentro de casa....

VIRGÍNIA- E nem ao menos tens pena do teu verdadeiro pai! Se visses como ele morreu! No meu quarto, Ana Maria, com um tiro, não no peito, não aqui (aperta o próprio ventre), mas no rosto... (com espanto). No rosto!

ANA MARIA- E queres que eu chore teu amante? Por que hei de chorar teu amante? (Rodrigues, 1981, p. $181,2^{\circ}$ quadro do $3^{\circ}$ ato)

Ana Maria confia em Ismael, no que ele diz e, acima de tudo, no mundo que ele criou para ela encarcerado como Virgínia dentro de um quarto. A raiva que Ana Maria nutre por sua mãe é acentuado quando Virgínia afirma que Ismael é negro, já que ele contara para Ana Maria que todos no mundo eram negros e só ele é branco. Ismael cria e nutre no mundo de Ana Maria a figura que ele busca ser e que não pode. Contudo, essa história que o leva é, também, a mesma história que o derrubará de seu trono quase divino. Virgínia, ao ver seu tempo chegar ao fim, apela para o mito que ela tanto desconstrói em toda peça ao afirmar: "toda mãe ama os filhos..." (Rodrigues, 1981, p.182).

As mãos aparecem no embate entre Ana Maria e Virgínia, contudo não portando sua habitual pulsão mortuária, mas a tentativa do carinho materno. Virgínia questiona se Ana Maria não sente todo o carinho do seu afago em seus cabelos, contudo a filha é, como Nelson Rodrigues usa duas vezes para caracterizá-la, "fanática". Ao invés do calor do carinho materno, o que Ana Maria apreende é a frieza no coração de Virgínia. Suas mentiras, na concepção da filha, são resultado da loucura da mãe. O cinismo de Virgínia ainda tenta convencer a filha ao afirmar que aceita de coração aberto todas as críticas e duras acusações da filha se calando apenas quando Ana Maria relembra da traição de Virgínia. Ana Maria é inteiramente de Ismael, fanática pelo Pai, único branco de todo o mundo e seu mundo é tão somente seu quarto. 
O coro encerra a peça profetizando a vida e a morte desse novo filho gerado no útero negro da branca Virgínia. Ana Maria dentro do vidro se debate, grita, mas não se escuta mais sua voz, até cair no chão, refazer os "estilhaços" do crucifixo com os braços e desfalecer. Mesmo sem olhos, cegados por aquele que ela adotou ser seu pai, Ana Maria encara os olhos petrificantes de Gorgó, enquanto Virgínia vitoriosa recebe Ismael em sua cama com o amor e a doçura das mulheres da vida, das prostitutas e, talvez, essa seja a redenção do casal ou apenas o reinício do ciclo de geração e imolação dos filhos do casal.

\section{Referências}

FACINA, Adriana. Santos e canalhas: Uma análise antropológica da obra de Nelson Rodrigues. Rio de Janeiro: Civilização Brasileira, 2004.

LOPES, Ângela Leite. Nelson Rodrigues: trágico, então moderno. 2ª Ed. Rio de Janeiro: Nova Fronteira, 2007.

MAGALDI, Sábato. Teatro da obsessão: Nelson Rodrigues. São Paulo: Global, 2004.

QUADROS, Dênis Moura de. A morte na carne e o desejo que escorre pelas mãos: Uma leitura da gorgonopoética das tragédias rodriguianas Anjo negro (1946) e Senhora dos afogados (1947). Rio de Janeiro: Bonecker, 2018.

RODRIGUES, Nelson. Anjo negro. In: Teatro completo de Nelson Rodrigues. V. 2- Peças Míticas. São Paulo: Nova Fronteira, 1981.

RUFFIOT, André. Fonction mytopoïétique de la famille: Mythe, fastasme, delire et leur gênese. Le Divan Familial, n. 26. 2011, p. 143-164.

SOUTO, Carla. Nelson "trágico" Rodrigues. Rio de Janeiro: Ágora da Ilha, 2001.

STEINER, George. A morte da tragédia. Trad. Isa Kopleman. São Paulo: Perspectiva, 2006.

VERNANT, Jean-Pierre. Mito e religião na Grécia Antiga. Trad. Joana Angélica D'Ávilla Melo. São Paulo: Martins Fontes, 2006.

Recebido em: 21/09/2018

Aprovado em: 15/01/2019 